Journal of Health Promotion and Behavior (2016), 1 (2): 70-78

https://doi.org/10.26911/thejhpb.2016.01.02.02

\title{
Health Belief Model: Health Preventive Behavior of Sexually Transmitted Infection in Female Sex Workers in Surakarta
}

\author{
Yenni Apriana Wulandari'), Nunuk Suryani 2), Eti Poncorini 3) \\ 1) Masters Program in Public Health, Sebelas Maret University, Surakarta \\ 2) Faculty of Teaching and Educational Sciences, Sebelas Maret University, Surakarta \\ 3) Faculty of Medicine, Sebelas Maret University, Surakarta
}

\begin{abstract}
Background: Sexually Transmitted Infection (STI), such as HIV/ AIDS, is a public health problem. The prevalence of HIV in Indonesia in 2014 was 32,711 cases, and the prevalence of AIDS was 5,494 cases. In 2015 the Municipality Health Office of Surakarta found 71 cases of STI, consisting of 18 cases of HIV, 47 cases of AIDS, and 6 cases of Siphilis. A female sex worker may have several sexual partners per day. As studies have shown, female sex workers have 12 times higher risk of HIV infection than loyal housewife. Condom use can reduce up to $85 \%$ risk of HIV transmission. This study aimed to investigate the factors affecting STI preventive behavior among female sex workers in Surakarta, using Health Belief Model (HBM).

Subjects and Method: This was an observational analytic study with cross-sectional design. This study was conducted in Banjarsari, Surakarta, Indonesia, from August to October 2016. A total of 130 female sex workers were selected at random. The independent variables were perceived susceptibility, perceived severity, perceived benefit, perceived barrier, cues to action, and selfefficacy. The dependent variable was STI preventive behavior. The data was collected by questionnaire and analyzed by logistic regression model.

Results: Perceived susceptibility ( $\mathrm{OR}=7.45 ; \mathrm{CI}=95 \% ; 1.61$ to $49.89 ; \mathrm{p}=0.012)$, severity ( $\mathrm{OR}=4.02$; $\mathrm{CI}=95 \% ; 1.14$ to $14.17 ; \mathrm{p}=0.310)$, benefit $(\mathrm{OR}=5.63 ; 95 \% \mathrm{CI} ; 1.10$ to $28.91 ; \mathrm{p}=0.390)$, barrier (OR = 0.18 ; $95 \% \mathrm{CI}$; 0.02 to $0.70 ; \mathrm{p}=0,018$ ), cues to action (OR=7.32; $\mathrm{CI}=95 \% ; 1,18$ to 29.29; $\mathrm{p}=0.050$ ), self-efficacy $(\mathrm{OR}=5.10$; $\mathrm{CI}=95 \%$; 1.10 to 23.58 ; $\mathrm{p}=0.370)$, had positive effects on STI preventive behavior.

Conclusion: Perceived susceptibility, severity, benefit, barrier, cues to action, self-efficacy, had positive effects on STI preventive behavior. This study supports the applicability of the HBM constructs when they are used to explain factors affecting STI prevention behavior.
\end{abstract}

Keywords: Health Belief Model, sexually transmitted infection, female sex worker

Correspondence:

Yenni Apriana Wulandari. Masters Program in Public Health, Sebelas Maret University, Surakarta

\section{LATAR BELAKANG}

Masalah kesehatan seksual dan reproduksi semakin menjadi perhatian di seluruh dunia. Keadaan ini berkaitan dengan perilaku seksual yang berakibat tertularnya penyakit infeksi menular seksual (IMS) (Widiantoro, 2014). Akibat yang ditimbulkan dari IMS, berpengaruh terhadap kualitas hidup dan kesehatan reproduksi, seperti kanker serviks, infertitilitas, kelahiran mati atau prematur, berat bayi lahir rendah, sifi- lis konginental, oftalmia neonatorum, hingga risiko tertularnya HIV. Bahkan seseorang yang pernah atau sedang menderita ulkus genitalis akan berisiko 50-300 kali tertular HIV, setiap hubungan seksual tanpa pelindung (Pedoman Nasional Penanganan IMS, 2011).

Infeksi Menular Seksual (IMS) adalah penyakit yang ditularkan melalui hubungan seksual, meskipun bisa juga ditularkan melalui ibu ke bayi, produk darah, transfer jaringan yang terkontaminasi, dan alat kese- 
hatan. Beberapa ini yang termasuk IMS antara lain gonore, klamidiosis, limfogranuloma venereum, sifilis, kankroid, granuloma inguinale, HIV, herpes genitalis, kutil kelamin, hepatitis virus, moluskum kontagiosum, trikomoniasis, kandidiasis, pedikulosis pubis, dan skabies (Kementerian Kesehatan RI, 2011).

Lebih dari 1 juta orang mengalami IMS setiap harinya. Setiap tahun sekitar 500 juta orang mengalami salah satu dari beberapa jenis IMS. IMS memiliki dampak besar pada kesehatan seksual dan reproduksi, dan juga dapat meningkatkan tiga kali lipat atau lebih risiko penularan HIV. WHO dan UNAIDS (2014), memperkirakan lebih dari 35.3 juta orang terinfeksi HIV di seluruh dunia, dan 90\% di negara-negara berkembang. Di Indonesia, kasus baru HIV positif setiap tahun mengalami peningkatan, pada tahun 2012 terdapat $21.511 \mathrm{ka}-$ sus, tahun 2013 terdapat 29.037 kasus, dan tahun 2014 terdapat 32.711 kasus. Kasus baru AIDS setiap tahunnya juga mengalami peningkatan, pada tahun 2012 terdapat 9.649 kasus, tahun 2013 terdapat 10.163 kasus, dan mengalami penurunan pada tahun 2014 terdapat 5.494 kasus (Kemenkes RI, 2015). Jumlah kasus baru HIV positif di Provinsi Jawa Tengah sebanyak 740 kasus dan peringkat 13 menurut provinsi di Indonesia. Data pada Kota Surakarta ditemukan 71 kasus IMS terdiri dari 18 orang HIV, 47 orang AIDS, dan 6 orang Sifilis (Dinkes Kota Surakarta, 2014).

Beberapa dekade terakhir, IMS di negara-negara berkembang menempati lima besar penyakit yang menyebabkan seseorang mendatangani fasilitas kesehatan. Diagnosis awal dan penanganan IMS yang tepat, penting dilakukan sebagai upaya pencegahan penularan HIV, selain itu, kejadian IMS juga dapat digunakan untuk mengetahui perilaku kesehatan seseorang (Agustina et al., 2015).
Penelitian tentang cara penularan IMS berkembang pesat sebagai dampak tingginya kasus HIV. Pemerintah memiliki 4 program utama untuk pencegahan penularan IMS bekerja secara komprehensif meliputi penguatan pemangku kepentingan di lokasi, komunikasi perubahan perilaku, manajemen pasokan kondom dan pelicin, serta pengobatan IMS di puskesmas, dengan sasaran utama, yaitu WPS dan pelanggan. Selain itu, juga dilakukan monitoring intensif pada setiap komponen, dan evaluasi perubahan perilaku. Pemerintah juga telah menyediakan klinik layanan IMS di puskesmas, klinik swasta, klinik perusahaan. Terdapat 245 klinik layanan IMS hingga tahun 2008 (Komisi Penanggulangan AIDS, 2010).

Tingginya prevalensi maupun insiden infeksi penyakit menular seksual (IMS) berkaitan dengan praktek perilaku pencegahan IMS dan HIV/AIDS yang masih sangat rendah, seperti rendahnya angka penggunaan kondom pada seks berisiko dan cukup tingginya angka berganti pasangan. Diperkirakan 75-80\% penularan terjadi melalui hubungan seksual, 5-10\% diantaranya melalui hubungan homoseksual (Depkes RI, 2006).

Pemerintah Kota Surakarta telah mendirikan 3 klinik layanan IMS, dimana dilakukan pemeriksaan sekret, konseling, terapi, penyuluhan, dan penapisan pada kelompok risiko tinggi, serta rujukan ke Klinik Voluntary Counseling and HIV Testing (VCT) untuk memastikan apakah seseorang tertular atau tidak virus HIV. Klinik IMS terdapat di RSUD dr. Moewardi, Puskesmas Manahan, dan Puskesmas Sangkrah (Dinkes Kota Surakarta, 2015).

Infeksi Menular Seksual akan ditularkan oleh orang yang berisiko tinggi, yakni orang yang berganti-ganti pasangan seksual (kelompok inti atau care group). Selanjutnya, kelompok inti akan menyebarkan pe- 
Journal of Health Promotion and Behavior (2016), 1 (2): 70-78

https://doi.org/10.26911/thejhpb.2016.01.02.02

nyakit IMS kepada kelompok pelanggan (kelompok perantara atau bridging population), hingga akhirnya kelompok perantara akan menularkan penyakitnya kepada pasangan seksual tetapnya, yaitu suami atau istri (Nicola et. al, 2006).

Wanita pekerja seksual (WPS) adalah seseorang yang menjual jasanya untuk melakukan hubungan seksual demi mendapatkan uang. Seorang WPS akan bergantiganti pasangan seksual setiap harinya, maka pengetahuan WPS tentang cara penularan IMS tentu akan berpengaruh terhadap perilaku kesehatan. Seorang WPS akan berisiko 12 kali lebih tinggi untuk tertular virus HIV daripada orang yang setia kepada pasangannya (WHO \& UNAIDS, 2014).

Seringkali, WPS menemui banyak hambatan dalam berperilaku seksual yang aman. Ketidak setaraan kekuasaan antara pria dan wanita, dimana WPS tidak bisa memilih dengan siapa, situasi apa, dan kapan melakukan hubungan seksual, kadangkala menjadi hambatan, karena tidak bisa melakukan diskusi secara terbuka mengenai perilaku seksual. Stigma negatif dari masyarakat, dikarenakan pekerjaan WPS sangat bertentangan dengan agama, budaya, dan adat istiadat. Faktor ekonomi menjadi hambatan yang sebagian besar dipakai sebagai alasan WPS untuk berperilaku seksual yang aman (Pedoman Nasional Penanganan IMS, 2011).

Health Belief Model (HBM) merupakan sebuah teori psikologi untuk memprediksi sebab munculnya perilaku kesehatan seseorang (Conner, 2003). Persepsi WPS bahwa dirinya sangat rentan terhadap IMS jika tidak berperilaku seksual yang aman. Persepsi bahwa penyakit IMS merupakan penyakit yang berbahaya, bahkan mengakibatkan kematian, serta adanya hambatan untuk melakukan pencegahan penularan IMS akan mempengaruhi peri- laku kesehatan WPS. Kesadaran berperilaku seksual yang aman, misalnya ketaatan penggunaan kondom akan dapat mengurangi $85 \%$ risiko penularan HIV (Vadodara, 2015).

Berdasarkan latar belakang tersebut, maka peneliti tertarik untuk meneliti health belief model (HBM) terhadap perilaku pencegahan IMS pada wanita pekerja seksual (WPS).Tujuan penelitian ini adalah mengetahui ada hubungan health belief model (HBM) tentang perilaku pencegahan infeksi menular seksual (IMS) pada wanita pekerja seksual (WPS).

\section{SUBJEK DAN METODE}

Jenis penelitian adalah analitik observasional dengan pendekatan cross sectional. Pelaksanaan pada Agustus - Oktober 2016 di Kecamatan Banjarsari Surakarta, Indonesia. Populasi penelitian sebanyak seluruh WPS di Kecamatan Banjarsari. Teknik sampling yang digunakan adalah simple random sampling, sampel sebanyak 130 WPS. Teknik pengumpulan data menggunakan kuesioner. Analisis data menggunakan analisis regresi logistik.

\section{HASIL}

\section{Karakteristik subjek penelitian}

Hasil karakteristik subjek penelitian pada tabel 1 menunjukkan bahwa dari 130 subjek penelitian sebagian besar berumur 45-55 tahun sebanyak 66 orang (50.8\%).

Sebagian besar subjek penelitian berpendidikan SD/SMP/Sederajat 77 orang (59.2\%). Sebagian besar subjek penelitian dari segi status pernikahan janda/cerai mati/cerai hidup 77 orang (59.2\%). Sebagian besar subjek penelitian lama kerja $>6$ bulan 98 orang (75.4\%). Sebagian besar subjek penelitian dilihat dari jumlah pe- 
langgan seminggu 67 orang (51.5\%). Sebagian besar subjek penelitian yang memiliki penghasilan $>$ UMR sebanyak 69 orang (53.1\%).

Tabel 1. Karakteristik subjek penelitian

\begin{tabular}{llcc}
\hline Karakteristik & \multicolumn{1}{c}{ Kriteria } & Frekuensi & Persentase (\%) \\
\hline Usia & 19-30 tahun & 17 & 13.1 \\
& 31-40 tahun & 47 & 36.2 \\
Pendidikan & 45-55 tahun & 66 & 50.8 \\
& Tidak tamat sekolah & 25 & 19.2 \\
\hline \multirow{5}{*}{ Status } & SD/SMP/Sederajat & 77 & 59.2 \\
Pernikahan & SMA/Sederajat/PTN & 28 & 21.5 \\
& Belum Menikah & 47 & 36.2 \\
& Menikah & 6 & 4.6 \\
Lama Kerja & Janda/Cerai mati/Cerai & 77 & 59.2 \\
Jumlah & hidup bulan & & \\
Pelanggan & 5 bulan & 98 & 75.4 \\
Penghasilan & 5 Orang & 32 & 24.6 \\
& S UMR & 67 & 51.5 \\
& $\leq$ UMR & 63 & 48.5 \\
\hline
\end{tabular}

Sebagian besar subjek penelitian yang memiliki persepsi kerentanan responden lemah 74 orang (56.9\%). Sebagian besar subjek penelitian memiliki persepi keparahan responden rendah dan tinggi sama sebanyak 65 orang (50\%). Sebagian besar subjek penelitian yang memiliki persepi manfaat responden tinggi sebanyak 66 orang (50.8\%). Sebagian besar subjek penelitian memiliki persepi hambatan responden lemah sebanyak 101 orang (77.7\%). Sebagian besar subjek penelitian memiliki efikasi diri responden tinggi 76 orang (58.5\%). Sebagian besar subjek penelitian memiliki stimulus tindakan (cues to action) responden baik 90 orang (69.2\%). Sebagian besar subjek penelitian memiliki persepi perilaku pencegahan IMS responden sehat sebanyak 81 orang (62.3\%).

\section{Analisis Multivariat}

Analisis data menggunakan digunakan untuk mengetahui hubungan variabel bebas (persepsi kerentanan, persepsi keparahan, persepsi manfaat, persepsi hambatan, efikasi diri, stimulus tindakan, dan variabel terikat (perilaku pencegahan IMS). Perhitungan menggunakan program SPSS.

Hasil analisis Tabel 2 menunjukkan ada hubungan persepsi kerentanan dengan perilaku pencegahan IMS secara signifikan. WPS dengan persepsi kerentanan kuat mempunyai kemungkinan 8.97 kali lebih besar untuk memiliki perilaku sehat dalam pencegahan IMS $(\mathrm{OR}=8.97 ; \mathrm{CI}=95 \% ; 1.61$ hingga 49.89; $\mathrm{p}=0.012)$.

Tabel 2. Hasil analisis regresi logistik tentang hubungan antara konstruk health belief model dengan perilaku pencegahan IMS

$\begin{array}{cccc}\text { Variabel } & \text { OR } & \text { CI 95\% } & \text { p }\end{array}$


Journal of Health Promotion and Behavior (2016), 1 (2): 70-78

https://doi.org/10.26911/thejhpb.2016.01.02.02

\begin{tabular}{lcccc}
\cline { 3 - 4 } & & Batas bawah & Batas atas & \\
\hline Persepsi Kerentanan & 8.97 & 1.61 & 49.80 & 0.012 \\
Persepsi Keparahan & 4.02 & 1.14 & 14.20 & 0.031 \\
Persepsi Manfaat & 5.63 & 1.09 & 28.90 & 0.039 \\
Persepsi Hambatan & 0.17 & 0.02 & 0.71 & 0.018 \\
Efikasi Diri & 7.32 & 1.83 & 29.30 & 0.005 \\
Stimulus Tindakan & 5.20 & 1.10 & 23.60 & 0.037 \\
N observasi & 130 & & & \\
-2 log likelihood & $71.80^{\mathrm{a}}$ & & & \\
Nagelkerke $\mathrm{R}^{2}$ & $73.3 \%$ & & & \\
\hline
\end{tabular}

Hasil analisis menunjukkan ada hubungan persepsi keparahan dengan perilaku pencegahan IMS secara signifikan. WPS dengan persepsi keparahan tinggi mempunyai kemungkinan 4.02 kali lebih besar untuk memiliki perilaku sehat dalam pencegahan IMS $(\mathrm{OR}=4.02 ; \mathrm{CI}=95 \% ; 1.14$ hingga 14.17; $\mathrm{p}=0.31$ ).

Hasil analisis menunjukkan ada hubungan persepsi manfaat dengan perilaku pencegahan IMS secara signifikan. WPS dengan persepsi manfaat tinggi mempunyai kemungkinan 5.63 kali lebih besar untuk memiliki perilaku sehat dalam pencegahan IMS (OR=5.63; CI=95\%; 1.10 hingga 28.91; $\mathrm{p}=0.390)$.

Hasil analisis menunjukkan ada hubungan persepsi hambatan dengan perilaku pencegahan IMS secara signifikan. WPS dengan persepsi hambatan kuat mempunyai kemungkinan 0,17 kali lebih besar untuk memiliki perilaku sehat dalam pencegahan IMS $(\mathrm{OR}=0.17 ; \mathrm{CI}=95 \% ; 0.02$ hingga $0.70 ; \mathrm{p}=0.018)$.

Hasil analisis menunjukkan ada hubungan efikasi diri dengan perilaku pencegahan IMS secara signifikan. WPS dengan efikasi diri kuat mempunyai kemungkinan 7.32 kali lebih besar untuk memiliki perilaku sehat dalam pencegahan IMS (OR= 7.32; $\mathrm{CI}=95 \% ; 1.83$ hinga 29.29; $\mathrm{p}=0.050$ ).

Hasil analisis menunjukkan ada hubungan stimulus tindakan dengan perilaku pencegahan IMS secara signifikan.
WPS dengan stimulus tindakan tinggi mempunyai kemungkinan 5.10 kali lebih besar untuk memiliki perilaku sehat dalam pencegahan IMS $(\mathrm{OR}=5.10 ; \mathrm{CI}=95 \% ; 1.10$ hingga 23.58; $\mathrm{p}=0.370$ ).

Nilai Negelkerke $R^{2}$ sebesar $73.3 \%$ berarti bahwa ke enam variabel bebas (persepsi kerentanan, persepsi keparahan, persepsi manfaat, persepsi hambatan, efikasi diri, dan stimulus tindakan, mampu menjelaskan perilaku pencegahan IMS pada WPS $73.3 \%$ dan sisanya yaitu sebesar 26.7\% dijelaskan oleh faktor lain di luar model penelitian.

\section{PEMBAHASAN}

\section{Pengaruh antara persepsi keren- tanan dengan perilaku pencegahan IMS pada WPS.}

Hasil penelitian menunjukan bahwa ada pengaruh antara persepsi kerentanan dengan perilaku pencegahan IMS pada WPS di Banjarsari Surakarta secara signifykan $\mathrm{p}=0.012$, dimana semakin kuat persepsi kerentanan seorang WPS, maka akan semakin besar kemungkinan memiliki perilaku sehat dalam pencegahan IMS.

Menurut Theory of Reasoned Action atau teori tindakan beralasan (Ajzen dan Fishbein, 1980 dalam Ika, H, 2015) merupakan teori kebalikan dari teori HBM (Rosenstock, 1988) mengemukakan bahwa norma sosial seseorang mengacu pada ke- 
yakinan dalam dirinya terhadap bagaimana dan apa yang dipikirkan dan dianggap penting (reference person) dan motivasi seseorang untuk mengikuti pikiran tersebut. Kemungkinan individu akan melakukan tindakan pencegahan tergantung secara langsung pada hasil dua keyakinan atau penilaian kesehatan (health belief), yaitu ancaman yang dirasakan dari sakit atau luka (perceived threat) dan pertimbangan keuntungan dan kerugian (benefits and costs) (Smet, 1994 dalam Ika, 2015). Perilaku tentang ancaman yang dirasakan berdasarkan pada ketidak-kekebalan yang dirasakan (perceived vulnerability) merupakan kemungkinan bahwa orang-orang dapat mengembangkan masalah kesehatan menurut kondisi (Ogden, 1996 dalam Ika, 2015). Hal tersebut menggambarkan bahwa adanya persepsi kerentanan terkena IMS dan HIV/ AIDS baik, maka dapat menimbulkan praktik yang baik dalam perilaku pencegahan IMS dan HIV/AIDS.

Hasil penelitian ini sejalan dengan penelitian Sirait et al. (2012) menjelaskan ada hubungan yang signifikan antara persepsi kerentanan dengan perilaku pencegahan penularan HIV/AIDS, dan semakin merasa risiko seseorang terhadap suatu penyakit maka tindakan pencegahan dilakukan akan semakin baik pula. Penelitian ini juga sejalan dengan penelitian Nurcholis A et al. (2008) menjelaskan bahwa ada hubungan antara persepsi kerentanan dengan praktik WPS jalanan dalam upaya perilaku pencegahan IMS dan HIV \& AIDS.

\section{Pengaruh antara persepsi kepa- rahan dengan perilaku pencegahan IMS pada WPS.}

Hasil penelitian menunjukan bahwa ada pengaruh antara persepsi keparahan dengan perilaku pencegahan IMS pada WPS di Banjarsari Surakarta secara signifikan $\mathrm{p}=0.031$, dimana semakin kuat persepsi ke- parahan seorang WPS, maka akan semakin besar kemungkinan memiliki perilaku sehat dalam pencegahan IMS .

Menurut Tanjung (2004), jika seseorang terkena IMS, maka akan meningkatkan risiko terkena HIV/AIDS, secara umum risiko meningkat menjadi 2-18 kali lipat lebih besar tergantung jenis IMS-nya. Tingkat persepsi keparahan dalam perilaku pencegahan IMS kemungkinan disebabkan seseorang yang hanya serius untuk aspek finansial dimana kerugian materiil berupa biaya pengobatan saja, sedangkan untuk aspek sosial kebanyakan seseorang tidak memiliki persepsi keparahan yang baik.

\section{Pengaruh antara persepsi manfaat dengan perilaku pencegahan IMS pada WPS.}

Hasil penelitian menunjukan bahwa ada pengaruh antara persepsi manfaat dengan perilaku pencegahan IMS pada WPS di Banjarsari Surakarta secara signifikan $p=$ o.039, dimana semakin kuat persepsi manfaat seorang WPS, maka akan semakin besar kemungkinan memiliki perilaku sehat dalam pencegahan IMS .

Hal ini sejalan dengan penelitian Enggarwati (2015) yang yang menyatakan bahwa ada hubungan antara persepsi manfaat yang dirasakan dengan perilaku pencegahan penularan HIV/AIDS. Semakin tinggi persepsi manfaat pencegahan terhadap IMS dan HIV \& AIDS semakin baik praktiknya dalam pencegahan penyakit IMS dan HIV \& AIDS.

Persepsi positif tentang manfaat penggunaan kondom pada Alat Bantu Kontrasepsi (ABK) akan sangat berpengaruh terhadap perilaku ABK dalam pemakaian kondom ketika berhubungan seksual dengan WPS. Semakin positif persepsi maka kemungkinan untuk konsisten dalam perilaku pemakaian kondom akan semakin besar (Maryani et al, 2012). 
Journal of Health Promotion and Behavior (2016), 1 (2): 70-78

https://doi.org/10.26911/thejhpb.2016.01.02.02

Teori Health Belief Model (Rosenstock, 1988 dalam Ika, H, 2015) dijelaskan bahwa persepsi positif perilaku pencegahan (perceived benefit) merupakan penilaian individu mengenai keuntungan yang didapat dengan mengadopsi perilaku kesehatan yang disarankan, walaupun responden sudah mengetahui persepsi manfaat pencegahan IMS, akan tetapi responden berpendapat bahwa jika melayani pelanggan dengan memakai kondom maka pelanggan tidak merasakan puas dan kemungkinan pelanggannya akan berkurang dan tidak bisa menolak pelanggan meski dalam keputihan atau setelah menstruasi, sehingga responden tidak berpraktik baik dalam pencegahan IMS dan HIV \& AIDS.

\section{Pengaruh antara persepsi hamba- tan dengan perilaku pencegahan IMS pada WPS.}

Hasil penelitian menunjukan bahwa ada pengaruh antara persepsi hambatan dengan perilaku pencegahan IMS pada WPS di Banjarsari Surakarta secara signifikan $\mathrm{p}=0.018$, dimana semakin lemah persepsi hambatan seorang WPS, maka akan semakin besar kemungkinan memiliki perilaku sehat dalam pencegahan IMS .

Hal ini sejalan dengan penelitian Enggarwati (2015) yang menunjukkan bahwa ada hubungan antara persepsi hambatan yang dirasakan dengan perilaku pencegahan penularan HIV/AIDS.

Teori Health Belief Model (Rosenstock, 1982) bahwa kemungkinan individu melakukan tindakan pencegahan tergantung secara langsung pada hasil dari dua keyakinan atau penilaian kesehatan yaitu ancaman yang dirasakan dari sakit dan pertimbangan tentang keuntungan dan kerugian (Machfoedz dan Suryani, 2009). Bagaimanapun sebuah tindakan dapat saja tidak diambil oleh seseorang meskipun individu tersebut percaya terhadap keun- tungan mengambil tindakan (Priyoto, 2014).

\section{Pengaruh antara stimulus tindak- an dengan perilaku pencegahan IMS pada WPS.}

Hasil penelitian menunjukan bahwa ada pengaruh antara stimulus tindakan dengan perilaku pencegahan IMS pada WPS di Banjarsari Surakarta secara signifikan $\mathrm{p}=0.050$, dimana semakin kuat stimulus tindakan seorang WPS, maka akan semakin besar kemungkinan memiliki perilaku sehat dalam pencegahan IMS .

Menurut HBM (Rosenstock, 1988), petunjuk untuk berperilaku diduga tepat untuk memulai proses perilaku atau disebut sebagai keyakinan terhadap posisi yang menonjol (salient position) berasal dari informasi baik dari luar atau nasehat mengenai permasalahan kesehatan missalnya dari media masa atau petugas kesehatan maupun dari dalam berupa gejala yang pernah dialami atau dirasakan. Tindakan kesehatan terdapat faktor pencetus untuk memutuskan menerima atau menolak alternatif tindakan tersebut. Isyarat ini dapat bersifat internal ataupun eksternal. Isyarat internal yaitu isyarat untuk bertindak yang berasal dari dalam diri individu. Isyarat eksternal yaitu isyarat untuk bertindak yang berasal dari interaksi inter sosial, misalnya media massa, pesan, nasehat, anjuran atau konsultasi dengan petugas kesehatan (Rosenstock, 1988 dalam Ika, 2015).

\section{Pengaruh antara efikasi diri dengan perilaku pencegahan IMS pada WPS.}

Hasil penelitian menunjukan bahwa ada pengaruh antara efikasi diri dengan perilaku pencegahan IMS pada WPS di Banjarsari Surakarta secara signifikan $\mathrm{p}=0.037$, dimana semakin kuat efikasi diri seseorang, 
maka akan semakin kuat perilaku pencegahan IMS pada WPS.

Persepsi tentang kemampuan diri yang tinggi akan berpengaruh terhadap pemakaian kondom pada ABK. Seorang ABK yang mempunyai persepsi kemampuan diri yang tinggi akan lebih besar kemungkinannya dalam perilaku pemakain kondom daripada yang mempunyai persepsi rendah (Sirait et. al., 2012), dimana pemakaian kondom dapat mencegah lebih dari 90\% penularan HIV/AIDS (Marfatia et al., 2015).

Penelitian ini sejalan dengan penelitian yang dilakukan oleh Nurcholis AB, Tinuk I, Syamsulhuda BM (2008) didapatkan bahwa responden yang mempunyai persepsi keyakinan diri yang kurang baik sebanyak 19 orang (45.2\%) dan yang mempunyai persepsi keyakinan diri baik sebanyak 23 orang (54.8\%). Hasil uji statistik yang menggunakan Uji Chi Square menunjukkan bahwa ada hubungan antara persepsi keyakinan diri dengan perilaku pencegahan penularan HIV/AIDS yang diperoleh dari nilai $\mathrm{p}=0.001$. Hasil uji statistik signifikan yang berarti bahwa semakin tinggi persepsi kemampuan diri dalam pencegahan terhadap IMS dan HIV/ AIDS semakin baik praktiknya dalam pencegahan penyakit IMS dan HIV/AIDS.

Teori Health Belief Model (Rosenstock, 1988 dalam Ika, 2015) dijelaskan bahwa seseorang umumnya tidak mencoba untuk melakukan sesuatu yang baru kecuali seseorang berpikir dapat melakukannya. Jika seseorang percaya suatu perilaku baru yang berguna (manfaat dirasakan), tetapi berpikir dia tidak mampu melakukan itu (penghalang dirasakan), kemungkinan bahwa hal itu tidak akan dilakukan.

Menurut Bandura bahwa self efficacy dapat mempengaruhi setiap tingkat dari perubahan pribadi, baik saat individu tersebut mempertimbangkan perubahan ke- biasaan yang berkaitan dengan kesehatan. Seseorang akan merasa yakin atas kemampuannya karena kehadiran pengalaman yang berkaitan dengan sebuah perilaku atau merasa yakin berdasarkan observasi yang dilakukan pada orang lain (Smet, 1997 dalam Edy, 2009).

Berdasarkan penjelasan di atas dapat disimpulkan bahwa ada hubungan positif antara Persepsi kerentanan, keparahan, anfaat, hambatan, efikasi diri, dan stimulus tindakan dalam teori HBM terhadap perilaku pencegahan IMS. Dengan demikian hasil penelitian ini sesuai dengan penelitian terdahulu dan teori yang ada.

Persepsikerentanan, keparahan, manfaat, hambatan, efikasi diri, dan stimulus tindakan dalam teori HBM terdapat hubungan dan pengaruh yang positif terhadap perilaku pencegahan IMS pada WPS.

\section{DAFTAR PUSTAKA}

Corner M, Norman P. (2003). Predicting Health Behavior, Research, and Practice with Social with Social Cognition Model. Buckingham: Open University Press.

Corner M (2010). Chapter 2: Cognitive Determinants of Health Behavior. Handbook of Behavioral Medicine. Spriger Science + Business Media, LLC. DOI 10.1007/978-0-387-09488-5_2.

Diakses tanggal 11 Juli 2016.

Ditjen PPM, PLP (1997). Badan Statistik Kesehatan. Jakarta: Kemenkes.

Departemen Kesehatan RI (2006). Pedoman Pelayanan Konseling dan Testing HIV/AIDS, Jakarta secara sukarela (Voluntary Counseling and Testing), Dirjen P2 \& PL, Jakarta.

Dinas Kesehatan Kota Surakarta (2014). Profil Kesehatan Provinsi Jawa Tengah Tahun 2014. Surakarta: Dinkes Surakarta. 
Journal of Health Promotion and Behavior (2016), 1 (2): 70-78

https://doi.org/10.26911/thejhpb.2016.01.02.02

Enggarwati (2015). Faktor-faktor yang Berhubungan dengan Perilaku Pencegahan Penularan HIV/AIDS pada Waria Pekerja Seks di Kabupaten Kudus Tahun 2015 (Studi Kasus) Waria Pekerja Seks di Wilayah Kabupaten Kudus. Kudus. Jurnal Kesehatan Masyarakat (1): 41-45.

Green LW, Kreuter MW (1999). Health Promotion Planning: An Ecological and Environmental Approach. Montain view, CA: Mayfield Publising Co.

Kementerian Kesehatan RI. (2007). Surveilans Terpadu Biologis Perilaku, Jakarta. (2011). Surveilans Terpadu Biologis Perilaku, Jakarta. (2011). Pedoman Nasional Penanganan IMS Tahun 2011. Dirjen Pengendalian Penyakit dan Penyuluhan Lingkungan. Jakarta.
(2015). Surveilans Terpadu Biologis Perilaku, Jakarta. Komisi Penanggulangan AIDS (2010). HIV/ AIDS dan Infeksi Menular Lainnya di Indonesia. Jakarta: KPA Books.

Priyoto (2014). Teori Sikap dan Perilaku dalam Kesehatan Dilengkapi Contoh Kuesioner. Cetakan ke 1. Medical Book. Pacitan: Nuha Medika

Rosenstock IM, Strecher VJ, Becker MH. (1988). Social Learning Theory and The Health Belief Model. Vol. 15. 175183. San Francisco. Diakses tanggal 12 Juli 2016.

World Health Organization, UNAIDS (2014). Guideliness for Second Generation Surveillance for HIV, The Next Decade. Geneva: World Health Organization. 